\title{
Disaster Public Health Surveillance Response Systems in Yogyakarta, Indonesia
}

\author{
Bella Donna $^{1}$, Endang Suparniati ${ }^{2}$, Madelina Ariani ${ }^{* 1}$ and Rossi Sanusi ${ }^{1}$ \\ ${ }^{1}$ Center for Health Policy and Management Faculty of Medicine UGM, Sleman, Indonesia; ${ }^{2}$ Dr Sardjito Hospital, Regional Referral \\ Hospital, MoH, Sleman, Indonesia
}

\section{Objective}

To examine whether the danger zone District Health Office (DHO) and sub-district Health Centers (HCs) were employing an inter-disaster Public Health Surveillance-Response (PH S-R) System after the October 2010 Mt Merapi eruption and a pre-disaster PH S-R System during the July 2013 Mt Merapi eruption.

\section{Introduction}

The October 2010 eruption of Mt Merapi (the most active volcano in the Indonesia that erupts at 5-years intervals) claimed 141 lives, injured 453 people and displaced at least 278,000 people. This geological event became a disaster as national and international agencies had to step in to assist the Yogyakarta Province and Sleman District Administrations in dealing with the devastation caused by the pyroclastic flows. Because of its cyclic nature the task of the local governments is to improve the hazard mitigation system and to increase the resiliency of the population.

On 22 July 2013 the Volcano spewed ash clouds and people of two villages of the Cangkringan Sub-District evacuated themselves to the local village halls. The hazards posed by the ash clouds of the volcano and by the displacement of vulnerable populations, did cause certain physical and emotional sufferings, but could be controlled by the local administration.

\section{Methods}

In-depth interviews regarding the S-R Systems used were conducted with the heads and staff of the Cangkringan HC and the Sleman DHO. Disease distribution reports and disaster management guidelines were requested from the respective surveillance and disaster management staff. Identification of diseases directly caused by the eruption and diseases that cause the population to become more vulnerable were based on data of patients from the danger zone villages who were admitted to Dr Sardjito Hospital during October-December 2010.

\section{Results}

During the 2010 Mt Merapi eruption HCs of the Sleman District surrounding the volcano (Cangkringan, Pakem, Ngemplak, and Turi) erected health posts at the evacuation points. These health posts provided medical care and sent daily reports to their respective $\mathrm{HCs}$ which were forwarded to the Sleman DHO. The data were not processed and analyzed at the HCs as well as at the DHO. Data of the Dr Sardjito Hospital showed that 286 victims were admitted during 26 October until 10 December 2010, 114 (40\%) from Cangkringan, 96 (34\%) from Pakem, 33 (11\%) from Ngemplak, and 43 (15\%) from Turi. Forty-two percent of the cases were pyroclastic flow injuries (e.g., burns, asphyxia, fractures) and the remainders were vulnerable population cases (e.g., chronic diseases, problem pregnancies, and births). During the July 2013 eruption the health post of the affected villages reported 350 evacuees and 7 cases.

\section{Conclusions}

The danger zone HCs and the DHO were conducting routine case recording and reporting during the quiet phase and eminent danger phase. To increase the resiliency of the population during the interdisaster phase it was suggested that the HCs and DHO adopt a PH S-R System that focuses on basic, primary, secondary, and tertiary preventions of priority diseases/conditions. To lessen physical and emotional sufferings during the pre-disaster phase it was proposed that the HCs and the DHO use a PH S-R System that is aimed at reducing the exposure and susceptibility of the stricken population to biological, physical-chemical, and psychological pathogens.

\section{Keywords}

Disaster Surveillance; Volcano Hazards; Displaced Populations; Surveillance-Response Systems

\section{References}

Church World Service Indonesia. 278,000 people evacuated as Mt. Merapi continues to rumble. Accessed 13 August 2013 from http:// www.cwsindonesia.or.id/en/news/

Seach, J. Merapi Volcano. Accessed 13 August 2013 from http://www. volcanolive.com/merapi.html

*Madelina Ariani

E-mail: madel_ariani@mail.ugm.ac.id 